\title{
MASS BALANCE STUDY OF A GLACIER SYSTEM FROM HYDROLOGICAL OBSERVATIONS IN LANGTANG VALLEY, NEPAL HIMALAYA
}

\author{
by \\ Tomomi Yamada, Hideako Motoyama
}

Institute of Low Temperature Science, Hokkaido University, Sapporo 060, Japan

Kadgha Bdr. THaPa

Tri-chandra Campus, Tribhuvan University, Kathmandu, Nepal

\section{ABSTRACT}

Hydrological and meteorological observations of river runoff, precipitation and air temperature were conducted 27 August to 26 October 1982, in Langtang Valley, Nepal Himalaya, whereby the mass balance of the glacier system there was estimated. Observed values suggest that (1) all glacier ablation and rainwater in the subwatershed of Langtang Valley drain into the river with the runoff coefficient of 1 ; (2) ablation of the glacier system can be estimated simply using a degree-day factor of $10 \mathrm{~mm} /$ degree-day; and (3) precipitation is considered uniform over the whole watershed. Assuming that the suggested phenomena persist throughout the year, records of monthly precipitation and monthly mean temperature in this valley, indicate that annual accumulation and ablation in the glacier system amount to $2000 \pm 200 \mathrm{~mm}$, respectively.

\section{INTRODUCTION}

Meltwater from the glaciers in Great Himalaya constitutes the important water resource in Nepal. Development and effective use of it requires an understanding of the hydrological characteristics of glacier-fed rivers. Similarly, if we can estimate the amount of glacier accumulation and ablation from hydrological observations, the total regimen of the mass balance in the glacier system of a watershed will be estimated.

Hydrological observations were conducted in Langtang Valley $\left(28^{\circ} 13^{\prime} \mathrm{N}, 85^{\circ} 13^{\prime} \mathrm{E}\right) 27$ August to 26 October 1982, i.e. from late monsoon season to post-monsoon season.

\section{HYDROLOGICAL OBSERVATIONS}

Langtang Valley is located in the southern front of the Great Himalayas, called Langtang Himal on the border region of Nepal and China, some $100 \mathrm{~km}$ north of Kathmandu: it is the headwater area of the River Trisuli in the Narayani River System. To compare the characteristics of discharges from a large and a small glacialized watershed, runof was measured in the Langtang Khola (Khola means a river in Nepalese), the main river of Langtang Valley consisting of many glacialized subwatersheds, and the smaller Lirung Khola, one of the tributaries of the Langtang Khola, which is fed only by Lirung Glacier (Yamada and others 1984) (Figure 1). Sites of hydrological observations are located at $3840 \mathrm{~m}$ a.s.l. in the Langtang Khola watershed (LAW) and at $4000 \mathrm{~m}$ a.s.1. near the end of Lirung Glacier in the Lirung Khola watershed (LIW). Meteorological elements were measured at Base House (BH) in Kyangchen Gompa (3920 m a.s.l.) near the two sites. These sites are respectively marked $\mathrm{S} 1, \mathrm{~S} 2$ and $\mathrm{BH}$ in Figure 1. The total area of LAW was $333 \mathrm{~km}^{2}$, of which $127 \mathrm{~km}^{2}(38 \%)$ was glacierized. LIW had an area of 13.8 $\mathrm{km}^{2}$, of which $6.2 \mathrm{~km}^{2}(45 \%)$ was glacierized.

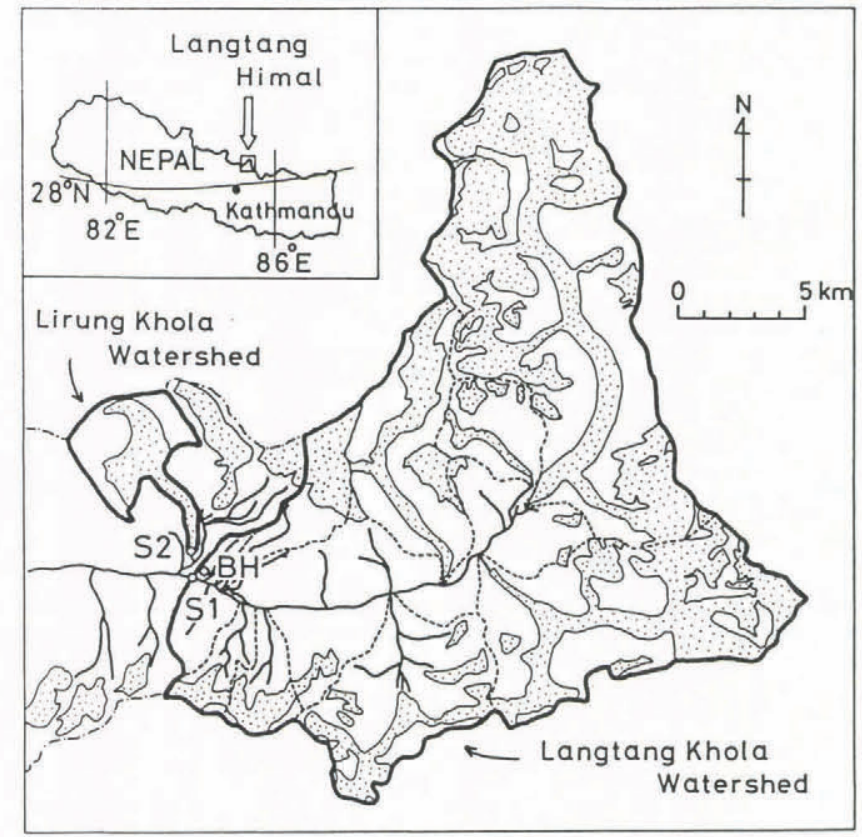

Fig.1. Topography of Langtang Valley. Thick solid lines are boundaries of Langtang Khola watershed, (observation site S1) and Lirung Khola watershed (observation site S2). BH: Base House for meteorological observations. Hatched areas indicate glaciers.

\section{HYDROLOGICAL ANALYSIS}

The total amount of runoff $r$ from a glacialized watershed per unit time is given by

$$
r=\alpha\left(M+P_{1}\right)
$$

where $\alpha$ is the runoff coefficient; $M$ and $P_{1}$ are the total amounts of ablation and rainwater respectively. For convenience the quantities will hereafter be considered areal means in a unit of length per unit time.

To estimate the amount of $\alpha$ in Equation 1, a comparison is made between $r$ observed and $M$ estimated in the rainless post-monsoon season when $P_{1}=0$ in both watersheds.

We first estimated $M$ by the degree-day method, given by

$$
M=(k / A) \int_{z_{e}}^{Z_{m}} T_{a}(z) A_{g}(z) d z
$$


The method has been widely used for evaluating snowmelt in mountain basins from air temperature data only ( Yamada 1982, Rango 1983). In this paper we assume simply the value of degree-day factor $k$ being constant. From the map, readings are taken of the glacier area, $A_{g}(z) d z$, between altitude $z$ and $z+d z$, the area $A$ of the watershed, and altitude $z_{e}$ of the glacier terminus. Air temperature $T_{a}(z)$ is calculated from $T_{a}$ observed at Base House $(\mathrm{BH})$ and lapse rate $\mathrm{r}$. The temperature $\mathrm{T}_{\mathrm{a}}\left(\mathrm{z}_{\mathrm{m}}\right)$ at the altitude $\mathrm{z}_{\mathrm{m}}$ of the upper limit of the ablation area is $0^{\circ} \mathrm{C}$. The value of $\mathrm{r}$ is measured in Langtang Valley as $1.0 \times 10^{-2}$ on the glaciers and $0.6 \times 10^{-2}{ }^{\circ} \mathrm{C} / \mathrm{m}$ in the glacier-free area. Constant $\mathrm{k}$ was obtained empirically in Nepal Himalaya, by linear extrapolation in Figure 6 of Ageta and others 1980 , with a value of $10 \mathrm{~mm} /$ degree-day.

It was found that $r=M$ in LIW, and $r=M+$ $1.7 \mathrm{~mm} /$ day in LAW, especially after 20 September, when the post-monsoon season started, as shown by thick solid line ( $r$ ) and dashed line (M) in the upper (LIW) and the lower figure (LAW) of Figure 2. In the lower figure, the residual ( $\mathrm{r}-1.7$ in LAW) is shown by the thin solid line.

Paying attention to the result obtained in LIW, it is clear that evapotranspiration $E$ and the change in groundwater storage $G$ are negligibly small; that is, runoff coefficient $\alpha$ in Equation 1 is approximately equal to 1; of rainwater runoff is also believed to be 1 . The hydrological characteristics, $\mathrm{E}=0$ and $\mathrm{G}=0$ seem to be reasonable in LIW, because of comparatively low air temperature and absence of a vegetative cover in Langtang Valley catchment, where the groundwater basin resulting from active movement of Lirung Glacier, and steep neighbouring unglaciated slopes, have little or no sedimentary covering. As for LAW, the value of 1.7 $\mathrm{mm} /$ day may imply daily runoff due to the change in groundwater storage, this value being comparatively large in comparison with the value of $r$ in the postmonsoon
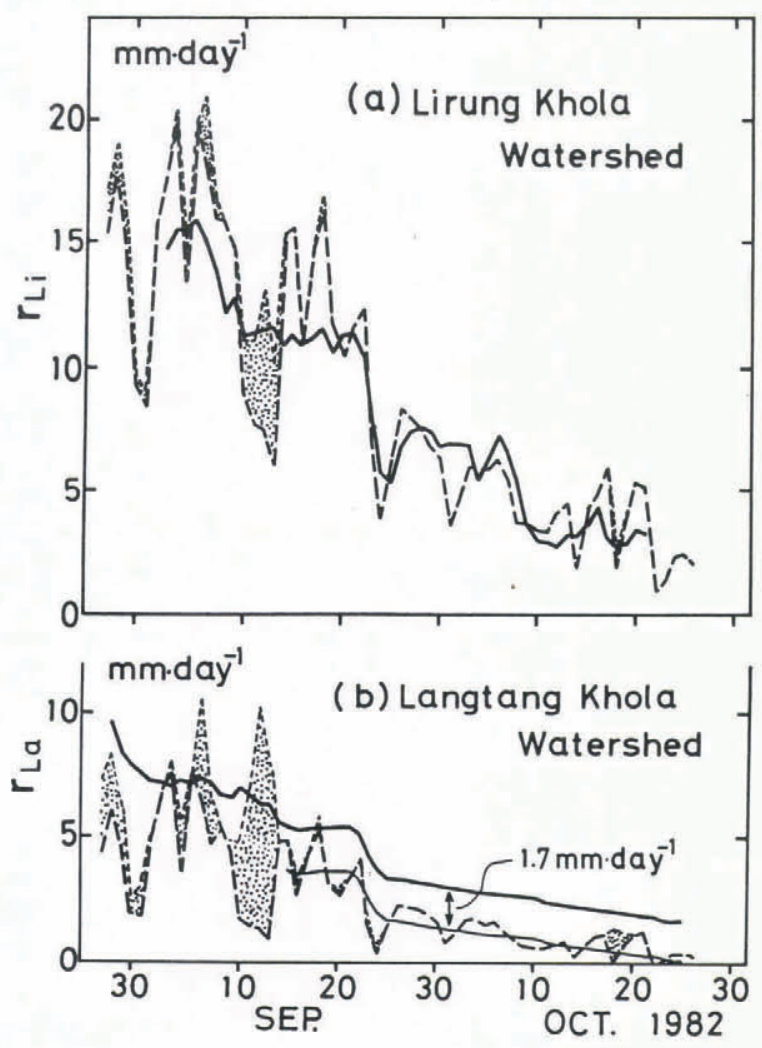

Fig.2. Comparison between observed daily runoff (thick solid line) and the sum of estimated daily ablation (thick dashed line) and estimated daily rainfall (thin dashed line with dotted areas). The thin solid line in the lower figure shows the residual $(\mathrm{r}-1.7 \mathrm{~mm} /$ day $)$ in Langtang Khola watershed. season. The groundwater basin in LAW may consist of the abundant sediment accumulated in the bottom of the large U-shaped Langtang Valley, in which a large amount of water has been contained as groundwater during the monsoon season.

The watershed LAW consists of many glacialized subwatersheds, each with hydrological features similar to those in LIW, because of topography and sediments. From LAW almost all the ablation products and rainwater are believed to discharge into the Langtang Khola, the main river of Langtang valley, and $\alpha=1$ as in LIW.

The relation of $P_{1}$ in LIW and LAW to the amount of precipitation $\mathrm{R}$ measured at $\mathrm{BH}$ is presumed to be

$$
P_{1}=B R A_{1} / A
$$

Rainfall area $A_{1}$, defined as the area where $T_{a}>2{ }^{\circ} \mathrm{C}$ because of the probability of rainfall being $50 \%$ at $2{ }^{\circ} \mathrm{C}$ (Higuchi 1977), is derived from the map and $T_{a}$ observed at $\mathrm{BH}$. As the difference $\mathrm{r}-\mathrm{M}$ obtained in the monsoon season agrees with $P_{1}$ calculated from Equation 3 , the best-fit value of correction factor $\beta$ is determined as $\beta=1$ by trial and error in both the watersheds. Values of $P_{1}$ are added to those of $M$ in figure 2, giving the dotted areas.

\section{MASS BALANCE OF THE GLACIER SYSTEM IN LANGTANG VALLEY}

Investigation was made of the mass balance of the glacier system in LAW, the first attempt in this region, from data of monthly precipitation $R_{M}$ and monthly mean air temperature $T_{M}$ at Kyangchen Gompa (BH), estimated by Ageta and others (1984). $P_{1}$ :

Accumulation $\mathrm{P}_{\mathrm{S}}$ is estimated in the same way as

$$
P_{S}=R A_{S} / A
$$

where $A_{S}$ is the solid precipitation area, $T_{M}<2{ }^{\circ} \mathrm{C}$ in LAW on the assumption that almost all solid precipitation that falls on the glacier-free area avalanches into the glaciers. Since Ageta (1976) has shown that $30 \%$ of precipitation occurs in the daytime $\left(06-18^{\mathrm{h}}\right)$ and $70 \%$ at night $\left(18-06^{\mathrm{h}}\right)$ in the deep valleys of Great Himalaya, day and night accumulation are calculated separately using monthly mean daytime $\left(\mathrm{T}_{\mathrm{MD}}\right)$ and nighttime $\left(\mathrm{T}_{\mathrm{MN}}\right)$ air temperatures estimated from $\mathrm{T}_{\mathrm{M}}$. Estimation is made by adapting $T_{M D}$ and $T_{M N}$ to $T_{M}$, evaluated from air temperature data measured at Lhajung $(4420 \mathrm{~m}$ a.s.1.) in the Khumbu region (Appendix in Seppyo 40, 1978), assuming harmonic diurnal variations.

Daily ablation $M$ in LAW is empirically related to daily mean air temperature $\mathrm{T}_{\mathrm{a}}$ at $\mathrm{BH}$, using Equation 2.

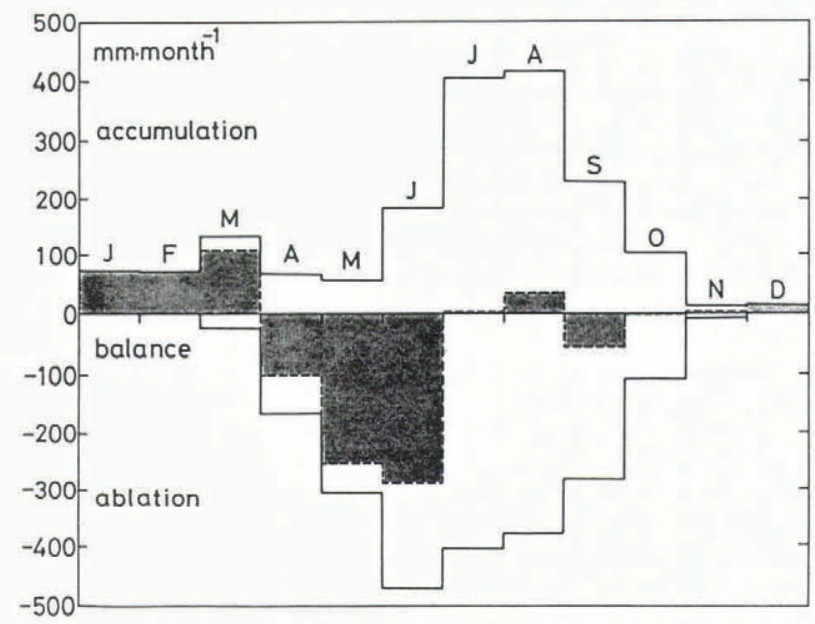

Fig.3. Monthly amounts (areal means over the glacier area) of accumulation, ablation and mass balance (hatched histograms) of the LAW glacier system. 
From this relation, values of $M$ are estimated from $T_{M}$ for each month of the year assuming that the above relation obtained from daily values of ablation and air temperature can be adapted for monthly values.

Figure 3 shows seasonal variations in accumulation, ablation and balance (hatched histograms) in the glacier system of LAW. $70 \%$ of accumulation occurred in the monsoon season from June to September. Monthly mass balances are negative and large from April to June. In conclusion, annual accumulation and annual ablation are roughly estimated at 1800 and $2200 \mathrm{~mm}$ respectively for the LAW glacier area. Since annual balance of a glacier should in general be close to zero, annual accumulation and annual ablation may fall in the range of $2000 \pm$ $200 \mathrm{~mm}$ in this region. The discrepancy between estimated values of accumulation and ablation may be caused by the large number of assumptions. Though we have no data for judging whether our values are reasonable or not, the sum of ablation $(820 \mathrm{~mm})$ and annual amount of rainfall $(340 \mathrm{~mm})$ over the whole LAW, ie $1160 \mathrm{~mm}$ of annual runoff, agrees fairly well with annual measured precipitation of $1009 \mathrm{~mm}$, assuming a negligibly small annual change in groundwater storage. This suggests that our method is reasonably accurate.

\section{REFERENCES}

Ageta Y 1976 Characteristics of precipitation during monsoon season in Khumbu Himal. Seppyo 38 (Special Issue): $85-88$

Ageta Y, Ohata T, Tanaka Y, Ikegami K, Higuchi $\mathrm{K}$ 1980 Mass balance of Glacier AX010 in Shorong Himal, East Nepal during the summer monsoon season. Seppyo 41 (Special Issue): $34-41$

Ageta Y, Yamada T, Thapa K B 1984 Climate of Langtang Valley. Glacial Studies in Langtang Valley, Data Center for Glacier Research, Japanese Society for Snow and Ice: 113-115

Higuchi K 1977 Effect of the nocturnal precipitation on the mass balance of the Rikha Samba Glacier, Hidden Valley, Nepal. Seppyo 39 (Special Issue): 43-49

Rango A 1983 Application of a simple snowmelt-runoff model to large river basins. 51st Annual Meeting Western Snow Conference April 19-21, 1983 Vancouver, Washington: $89-99$

Yamada T 1982 Studies on accumulation-ablation processes and distribution of snow in mountain regions, Hokkaido. Contributions from the Institute of Low Temperature Science A, 31: 1-33

Yamada T, Motoyama H, Thapa K B 1984 Role of glacier meltwater in discharge from the glaciated watersheds of Langtang Valley, Nepal Himalaya. Glacial studies in Langtang Valley, Data Center for Glacier Research, Japanese Society for Snow and Ice: $61-7$ 